\title{
Potassium permanganate effects in postharvest conservation of the papaya cultivar Sunrise Golden
}

\author{
Danieele Fabíola Pereira Silva(1), Luiz Carlos Chamhum Salomão(1), Dalmo Lopes de Siqueira(1), \\ Paulo Roberto Cecon ${ }^{(2)}$ and Aline Rocha ${ }^{(1)}$
} (1)Universidade Federal de Viçosa (UFV), Departamento de Fitotecnia, Av. P.H. Rolfs, s/no, CEP $36570-000$ Viçosa, MG, Brazil.
E-mail: danieele@ufv.br, Isalomao@ufv.br, siqueira@ufv.br, rochaline@hotmail.com (2)UFV, Departamento de Informática. E-mail: cecon@dpi.ufv.br

\begin{abstract}
The objective of this work was to evaluate the effects of $\mathrm{KMnO}_{4}$ on the extension of postharvest life of 'Sunrise Golden' papaya, stored under modified atmosphere and refrigeration. Fruit with up to $10 \%$ yellow peel were harvested in a commercial orchard in Linhares, state of Espírito Santo, Brazil. Sets of three fruit (unit mass of $289.9 \pm 18.5 \mathrm{~g}$ ) were wrapped in low-density polyethylene films ( $28 \mu \mathrm{m}$ thick) containing sachets of $\mathrm{KMnO}_{4}$ at $0,0.5,1,1.5$, and $2 \mathrm{~g}$ per bag. The bags were sealed and stored at $10.4 \pm 0.9^{\circ} \mathrm{C}$ and $90 \pm 5 \%$ relative humidity for 25 days. After this period, the fruit were removed from the bags and maintained at $21 \pm 0.8^{\circ} \mathrm{C}$ and $90 \pm 5 \%$ relative humidity until complete ripening. Four days after bag sealing, $\mathrm{CO}_{2}$ concentration stabilized in all treatments, and was higher in bags without $\mathrm{KMnO}_{4}$. In all treatments, fruit reached the climacteric respiratory peak on the third day after bag removal, coinciding with peel color index of 3.5. Increasing the $\mathrm{KMnO}_{4}$ dose reduced the losses in fruit fresh matter, consistency and pulp electrolyte leakage. Potassium permanganate was effective in maintaining the fruit at the pre-climacteric stage during the 25-day storage, and did not interfere with normal ripening after bag removal.
\end{abstract}

Index terms: Carica papaya, ethylene absorber, modified atmosphere, ripening, shelf life, storage.

\section{Permanganato de potássio na conservação pós-colheita da cultivar de mamão Sunrise Golden}

Resumo - O objetivo deste trabalho foi avaliar os efeitos do $\mathrm{KMnO}_{4}$ na extensão da vida pós-colheita da cultivar de mamão Sunrise Golden, armazenada em atmosfera modificada e refrigeração. Frutos com até 10\% da área superficial da casca amarela foram colhidos em pomar comercial em Linhares, ES. Conjuntos de três frutos (massa unitária de $289,9 \pm 18,5 \mathrm{~g}$ ) foram acondicionados em filmes de polietileno de baixa densidade (28 $\mu \mathrm{m}$ de espessura), com sachês de $\mathrm{KMnO}_{4}$ nas doses de $0,0,5,1,1,5$, e $2 \mathrm{~g}$ por embalagem. As embalagens foram hermeticamente fechadas e armazenadas a $10,4 \pm 0,9^{\circ} \mathrm{C}$ e $90 \pm 5 \%$ de umidade relativa (UR), por 25 dias. Após esse período, os frutos foram retirados das embalagens e armazenados a $21 \pm 0,8^{\circ} \mathrm{C}$ e $90 \pm 5 \%$ de UR até o completo amadurecimento. A concentração de $\mathrm{CO}_{2}$ estabilizou-se, em todos os tratamentos, no quarto dia após o fechamento das embalagens e foi maior nas embalagens sem $\mathrm{KMnO}_{4}$. Os frutos de todos os tratamentos atingiram o pico climatérico respiratório no terceiro dia após a retirada das embalagens, o que coincidiu com o índice de cor da casca 3,5. O aumento da dose de $\mathrm{KMnO}_{4}$ resultou em menor perda de matéria fresca do fruto, menor perda de consistência e menor extravasamento de eletrólitos da polpa. $\mathrm{O} \mathrm{KMnO}_{4}$ foi eficiente em manter os frutos no estádio pré-climatérico, durante os 25 dias de armazenamento, e não interferiu no amadurecimento normal após a retirada da embalagem.

Termos para indexação: Carica papaya, absorvedor de etileno, atmosfera modificada, amadurecimento, vida de prateleira, armazenamento.

\section{Introduction}

Papaya is a tropical fruit with a considerable economic potential for internal and external market (Souza et al., 2005). It is rather perishable with small postharvest life, even when kept under refrigeration, thus the importance to study alternatives to increase its durability (Morais et al., 2008). Papaya high perishability is a result of its high water content and high-to-very high respiratory rate, which results in high heat production during storage and easily damaged soft structure (Balbino, 2003). It is a climacteric fruit, whose transformations resulting from the ripening occur rapidly after harvesting the physiologically mature fruit, triggered by elevation of ethylene evolution and increases in respiratory rate. 
To enhance the postharvest life of papaya, it is necessary to use technologies that reduce or remove the ethylene of the storage environment, and this can be achieved by using products such as $\mathrm{KMnO}_{4}$. This product oxidizes the ethylene produced by the fruit during ripening, extending the pre-climacteric period and the post-harvest life (Resende et al., 2001). The oxidation of ethylene by $\mathrm{KMnO}_{4}$ leads to the formation of water and $\mathrm{CO}_{2}$ (Sorbentsystems, 2005).

Refrigeration is one of the most important methods used to delay the processes of senescence. When combined with modified atmosphere, it causes ripening delay and keeps fruit according to market needs (Chitarra \& Chitarra, 2005). Modified atmosphere is a quite versatile, relatively simple, and low cost technology that can be applied to various types of fruit and vegetables (Neuwald et al., 2005). Its efficacy can be increased by combining it with ethylene absorbers, such as potassium permanganate $\left(\mathrm{KMnO}_{4}\right)$. According to Cenci et al. (1999), applying $\mathrm{KMnO}_{4}$ on 'Sunrise Solo' papaya, stored at $10^{\circ} \mathrm{C}$ over 28 days, reduced consistency loss during storage.

The effects of the absorption of ethylene on post-harvest life enhancement are less evident than the ones of low temperature. In avocado stored at $7^{\circ} \mathrm{C}$, the $\mathrm{CO}_{2}$ concentration inside the packaging with ethylene absorber was slightly lower than in the packaging without this absorber, while at $3^{\circ} \mathrm{C}$, $\mathrm{CO}_{2}$ concentration in packaging was slightly higher, when ethylene absorber was used (Zamorano et al., 1994).

Strawberries packed with PVC film containing $\mathrm{KMnO}_{4}$, stored at $1^{\circ} \mathrm{C}$, showed decreased respiratory rate and increased storage life from 20 to 30 days, maintaining sugar/acid ratios, soluble solids content and firmness acceptable for consumption (Hao \& Hao, 1993).

Experimental conditions used by several authors (Hong et al., 1996; Bhadra \& Sen, 1997; Kim \& Wills, 1998; Chaves et al., 2007) vary regarding polyethylene film thickness, use of bag perforations, temperature, ethylene absorbers usage etc. Nevertheless, all of them concluded that polyethylene film packing, together with ethylene absorbers and low temperatures led to a considerable increase in fruit shelf life, by increasing $\mathrm{CO}_{2}$ concentration, reducing water loss and respiration, inhibiting ethylene activity and, consequently, reducing the metabolism of the fruit.
The objective of this work was to evaluate the effect of different doses of $\mathrm{KMnO}_{4}$ on the extension of postharvest life of 'Sunrise Golden' papaya, stored under modified atmosphere and refrigeration.

\section{Materials and Methods}

Fruit were obtained from a commercial orchard in Linhares (19 $23^{\prime} 28^{\prime \prime} \mathrm{S}, 40^{\circ} 04^{\prime} 20^{\prime \prime} \mathrm{W}$, and $33 \mathrm{~m}$ altitude), in the northern region of the state of Espírito Santo, Brazil.

'Sunrise Golden' papayas were harvested at ripening stage 1 , i.e., with up to $10 \%$ of the surface area presenting yellow color, on January 02, 2006. After harvest, the fruit were transported to the packinghouse where they were selected according to size and ripening stage (Martins \& Malavasi, 2003). Fruit presenting physical flaws and physiological disturbances were discharged. Normal healthy fruit were washed in running water, treated with $1 \%$ aqueous chlorine solution, placed in cardboard boxes and transported to Universidade Federal de Viçosa, Laboratório de Análise de Frutas, in Viçosa, MG, Brazil, reaching their destination approximately 20 hours after harvest.

New selection and standardization were done in the laboratory, using only fruit with $289.90 \pm 18.49 \mathrm{~g}$ mass. Selected fruit were immersed in fungicide solution Prochloraz (Sportak 450 CE, Hoechst Schering AgrEvo UK Ltd., England), at $49.5 \mathrm{~g} 100 \mathrm{~L}^{-1}$ of water, for $5 \mathrm{~min}$, and air-dried.

Sets of three fruit were packed in hermetic low-density polyethylene bags $(35 \mathrm{~cm}$ high x $25 \mathrm{~cm}$ wide, and $28 \mu \mathrm{m}$ thick), from which air was partially removed with a vacuum cleaner. Expanded vermiculite sachets impregnated with $\mathrm{KMnO}_{4}$ at five doses $(0$, $0.5,1.0,1.5$, and $2 \mathrm{~g}$ per bag) were placed inside each bag. After being packed, fruit were stored during 25 days in a cold chamber, at mean temperature of $10.4 \pm 0.9^{\circ} \mathrm{C}$ and air relative humidity of $90 \pm 5 \%$. After this period, the fruit were removed from the bag and kept in the chamber at mean temperature of $21 \pm 0.8^{\circ} \mathrm{C}$, until complete ripening. Samplings were made in the beginning of the storage, in the day that fruit were removed from the bags (on the $25^{\text {th }}$ storage day), and after 1, 2, 3, 5 and 6 days of bag removal.

The analyses conducted were: $\mathrm{CO}_{2}$ evolution and $\mathrm{CO}_{2}$ concentration inside the polyethylene bags, determined by gas chromatography; peel color 
evolution, determined by visual scale described by Martins \& Malavasi (2003), with increasing values of 1 to 5 attributed according to yellow peel surface area percentage; fresh matter loss, determined by gravimetry, considering the difference between fruit initial weight, and weight obtained in each sampling period; pulp consistency, determined by applying force, using a $12 \mathrm{~mm}$ diameter gauge of a digital penetrometer Shimpo model DFS 100 (Digital Force Gauge) until the tissue no longer presented resistance; and electrolyte leakage, performed according to Serek et al. (1995), with modifications. A portion of the peel was removed from the median region of the fruit without injuring the pulp, and also a pulp cylinder per fruit $(1.14 \mathrm{~cm}$ diameter per $1-\mathrm{cm}$ thick) using a metallic cork borer. The cylinder was washed in distilled water and superficially dried with absorbing paper, followed by a 2 -hour incubation in assay tubes containing $15 \mathrm{~mL}$ distilled water, under ambient conditions. Electric conductivity of the water was measured with a Schot model CG 853 conductivity meter. Later, the assay tubes containing the pulp cylinders were autoclaved $\left(121^{\circ} \mathrm{C}\right.$ at $1.5 \mathrm{~atm}$ ) for $30 \mathrm{~min}$, and electric conductivity was measured again. Finally, the total soluble solids (TSS) content was measured with the help of a manual refractometer Atago model N1, with reading range from 0 to $32^{\circ}$ Brix.

The experiment was placed in a completely randomized design, in split plot arrangement, with three replicates and three fruit experimental unit. Plots consisted of $\mathrm{KMnO}_{4}$ doses, and the split plots of the six sampling days after fruit removal from the bags. The Dunnett test was carried out at 5\% probability to compare treatment means from the beginning of storage and from the day the fruit were removed from the bags.

To analyze the $\mathrm{CO}_{2}$ concentrations inside the bags, another experiment was set up with the five previously used $\mathrm{KMnO}_{4}$ doses and five replicates, with a three-fruit experimental unit in a completely randomized design. Silicon septa were made and pasted on the bags. The gas bubbles formed inside silicon septa were removed with a 1-mL hypoderm syringe. The analyses were conducted at 4, 8, 12 and 24 hours and after 2, 3, 4, $5,6,7,8,9,10,11,12,21,24$ and 25 storage days. Descriptive statistical analysis was made.

\section{Results and Discussion}

Carbonic dioxide concentration increased until the $4^{\text {th }}$ day in all treatments, and the bags without $\mathrm{KMnO}_{4}$ accumulated more $\mathrm{CO}_{2}$ (Figure 1). The bags with $1.5 \mathrm{~g}$ of $\mathrm{KMnO}_{4}$ maintained a lower concentration of $\mathrm{CO}_{2}$ during most part of the experimental period. From the $8^{\text {th }}$ to the $12^{\text {th }}$ storage day, a reduction in $\mathrm{CO}_{2}$ concentration was observed in all treatments, remaining stable until the $24^{\text {th }}$ day.

Oliveira-Júnior et al. (2004) worked with 'Sunrise Golden' papaya in cardboard boxes coated with films (LDPE - $30 \mu \mathrm{m}$ thick) containing nine fruit with $2.5 \mathrm{~g}$ of $\mathrm{KMnO}_{4} \mathrm{~kg}^{-1}$, stored at ambient temperature for 12 days; these authors observed that the concentration of $\mathrm{CO}_{2}$ stabilized at $9.6 \%$ in bags without $\mathrm{KMnO}_{4}$. According to them, treatment with $\mathrm{KMnO}_{4}$ presented decreasing $\mathrm{CO}_{2}$ concentration tendency reaching $11.5 \%$ of $\mathrm{CO}_{2}$, at the $2^{\text {nd }}$ day of storage, and $8.2 \%$ in the $12^{\text {th }}$ day.

From the $1^{\text {st }}$ to the $24^{\text {th }}$ day of storage, it was observed that $\mathrm{CO}_{2}$ concentration inside the bags ranged between 5 and $10 \%$ in $\mathrm{KMnO}_{4}$ treated fruit, which, according to Gomez et al. (1999), is considered excellent for papaya storage under modified atmosphere, temperature varied between 10 and $15^{\circ} \mathrm{C}$. However, in treatments without $\mathrm{KMnO}_{4}, \mathrm{CO}_{2}$ concentration inside the bags was above $10 \%$ in the $3^{\text {rd }}$ storage day, which may cause

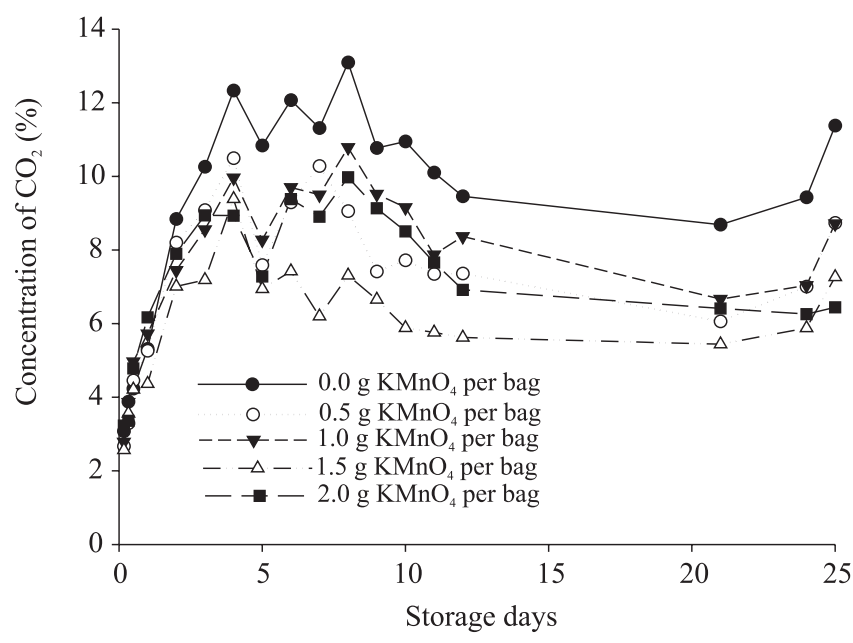

Figure 1. Carbon dioxide concentration inside the 'Sunrise Golden' papaya bag treated with different doses of $\mathrm{KMnO}_{4}$, during 25 days of storage at $10.4 \pm 0.9^{\circ} \mathrm{C}$. 
physiological disorders in papaya, such as change from aerobic to anaerobic respiratory route (Taiz $\&$ Zeiger, 2009). This type of respiration produces modifications in the flavor and aroma of the fruit, and breaks the structural components of the tissues, causing softening (Chitarra \& Chitarra, 2005).

Carbon dioxide evolution had statistical difference in treatments 0 and $0.5 \mathrm{~g}$ of $\mathrm{KMnO}_{4}$ per bag, between means at the storage beginning and after 25 days (Table 1). Fruit treated with 0 and $0.5 \mathrm{~g}$ of $\mathrm{KMnO}_{4}$ had their metabolism accelerated during storage, probably as a result of greater accumulation of ethylene in the bags. The opposite occurred in the three largest doses, highlighting the efficiency of $\mathrm{KMnO}_{4}$ in removing ethylene from the ambient.

The fruit from treatment without $\mathrm{KMnO}_{4}$ had higher $\mathrm{CO}_{2}$ evolution in the three first days after bag removal (Figure 2). In this treatment, climacteric rise in the respiration began after bag removal, while in the treated fruit it occurred between the $2^{\text {nd }}$ and $3^{\text {rd }}$ days. In all treatments, climacteric peak occurred on the $3^{\text {rd }}$ day after bag removal, and nontreated fruit had higher $\mathrm{CO}_{2}$ evolution at the climacteric peak. This higher $\mathrm{CO}_{2}$ evolution can be explained by the physiological stress caused by high concentration of this gas inside the bag (Figure 1), during refrigerated storage (Chitarra \& Chitarra, 2005). Fruit in treatments reached the postclimacteric phase beginning at the $3^{\text {rd }}$ day, although their peel had not yet reached full yellow coloration (Figure $3 \mathrm{~A}$ ).

Peel color index (Table 1) did not show statistical difference between means at the storage beginning and after 25 days in all treatments, indicating that these fruit remained unripe during the 25 days of storage. This result is similar to the one reported by
Silva (1995), who observed completely green fruit after 21 days of storage, working with 'Sunrise Solo' Improved Line $72 / 12$ stored at $10^{\circ} \mathrm{C}$ and packed in low density polyethylene film.

After bag removal, a sigmoid evolution of the peel color index was observed according to the evaluation day, for each $\mathrm{KMnO}_{4}$ dose (Figure $3 \mathrm{~A}$ ). In treatment without $\mathrm{KMnO}_{4}$, peel color index evolved quickly, while in the others it was slower, suggesting the effect of $\mathrm{KMnO}_{4}$ even after sachet and bag removal. In this treatment, color index was 4.3 , in the $3^{\text {rd }}$ day of evaluation, while in other treatments color index was 3.5 , in that same day. In commercial terms, this difference is advantageous, since the fruit could remain for longer periods on the supermarket shelves, resulting in a longer commercialization and consumption period. On the $6^{\text {th }}$ day of storage, fruit of all treatments showed peel color index above 4.5, considered acceptable for consumption.

The fresh matter loss showed statistical difference between means at the storage beginning and after 25 days, in all treatments (Table 1), since zero fresh matter loss was considered to occur in the beginning of storage. However, fresh matter loss was small in all treatments. According to Rocha (2005) and Galvão et al. (2008), this can be explained by the low temperature used in storage, which decelerates metabolism and turns the plastic film denser and less permeable to water vapor; consequently, relative humidity becomes higher inside the package, reducing transpiration.

Fresh matter loss increased along the evaluation days, at each dose of $\mathrm{KMnO}_{4}$ (Figure $3 \mathrm{~B}$ ). This is explained by the process of ripening, because the cellular membranes lose their permeability as the fruit ripe, increasing transpiration and respiration

Table 1. Carbon dioxide evolution, peel color index (CI) ${ }^{(1)}$, fresh matter loss (FML), pulp consistency (PC), electrolyte leakage (EL), and total soluble solids content (TSS) of 'Sunrise Golden' papaya treated with different doses of $\mathrm{KMnO}_{4}$, after 25 days of storage.

\begin{tabular}{|c|c|c|c|c|c|c|}
\hline Treatment & $\begin{array}{c}\mathrm{CO}_{2} \text { production } \\
\text { (mg CO} \mathrm{kg}^{-1} \text { per hour) }\end{array}$ & CI & FML (\%) & $\mathrm{PC}(\mathrm{kPa})$ & EL $(\%)$ & TSS $\left({ }^{\circ}\right.$ Brix $)$ \\
\hline $0.0 \mathrm{~g} \mathrm{KMnO}_{4}$ per bag & $117.48^{*}$ & 1.4 & $0.941 *$ & 2,205 & 14.929 & $10.8 *$ \\
\hline $0.5 \mathrm{~g} \mathrm{KMnO}_{4}$ per bag & $122.79^{*}$ & 1.2 & $1.046^{*}$ & 2,443 & 12.432 & $10.7 *$ \\
\hline $1.0 \mathrm{~g} \mathrm{KMnO}_{4}$ per bag & 108.09 & 1.2 & $1.089 *$ & 2,553 & 11.207 & $10.7^{*}$ \\
\hline $1.5 \mathrm{~g} \mathrm{KMnO}_{4}$ per bag & 80.29 & 1.0 & $1.176^{*}$ & 2,440 & 9.604 & 10.4 \\
\hline $2.0 \mathrm{~g} \mathrm{KMnO}_{4}$ per bag & 107.30 & 1.0 & $1.126^{*}$ & 2,561 & 11.749 & 9.9 \\
\hline Storage beginning & 94.64 & 1.0 & 0.000 & 2,540 & 9.389 & 9.4 \\
\hline
\end{tabular}


(Figure 2) and, consequently, augmenting fresh matter loss.

The treatments with 0 and $1 \mathrm{~g}$ of $\mathrm{KMnO}_{4}$ per bag had greater fresh matter loss throughout the evaluation days, corresponding to 2.86 and $2.54 \%$, respectively, on the $6^{\text {th }}$ day after bag removal. Fruit in all treatments had fresh matter loss above $2 \%$ on the $6^{\text {th }}$ day after bag removal, but such loss is not sufficient to cause wilting neither to hinder fruit commercialization.

Cenci et al. (1999) worked with 'Sunrise Solo' papaya sold in cardboard boxes without plastic film, containing 12 fruit and two sachets of $1 \mathrm{~g}$ each of $\mathrm{KMnO}_{4}$, and concluded that the use of ethylene absorber reduced mass loss $22.5 \%$ in average compared to fruit without $\mathrm{KMnO}_{4}$. In addition, mass loss in the nontreated fruit ranged from 14.7 to $33.8 \%$ over 31 storage days $\left(27\right.$ days at $10^{\circ} \mathrm{C}+4$ days at $20^{\circ} \mathrm{C}$ ).

The pulp consistency did not show statistical difference between means at the storage beginning and after 25 days in all treatments (Table 1). The fact that this variable did not differ after 25 days of storage in treatment without $\mathrm{KMnO}_{4}$ shows that refrigeration and modified atmosphere were efficient in inhibiting loss of pulp consistency. Different results were found by Cenci et al. (1999), who reported that fruit exposed to ethylene absorber had smaller consistency loss during 31 storage days compared to the nontreated fruit.

The nontreated fruit had a more softened pulp on day 0 and an accelerated posterior reduction in consistency

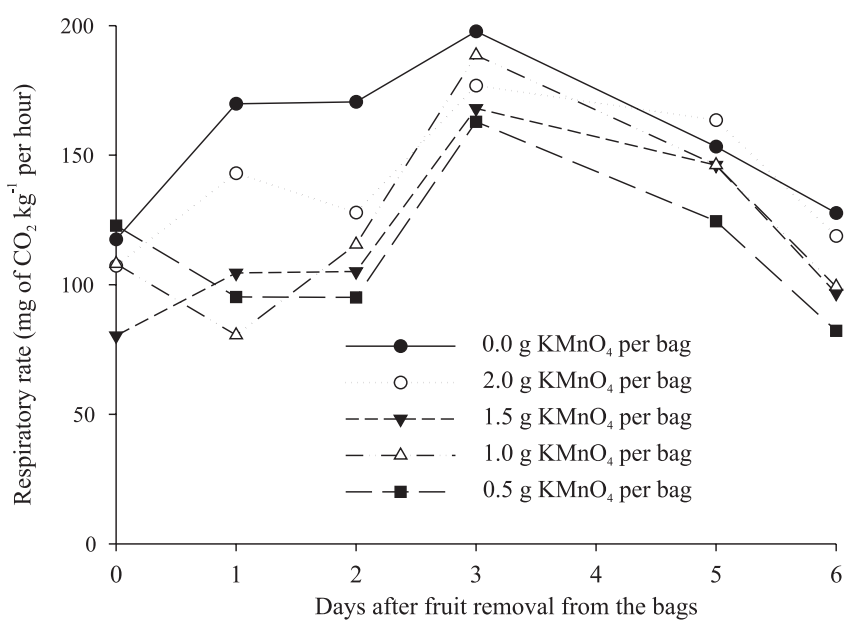

Figure 2. Respiratory rate after fruit removal from the bags of 'Sunrise Golden' papaya treated with different doses of $\mathrm{KMnO}_{4}$ and kept at $21 \pm 0.8^{\circ} \mathrm{C}$.
(Figure $3 \mathrm{C}$ ). The treated fruit kept their consistency high until the $2^{\text {nd }}$ day after bag removal, reducing it rapidly after that. The more marked consistency reduction after the $2^{\text {nd }}$ day for the treated fruit coincided with the start of the climacteric rise in respiration (Figure 2). These results agree with those obtained by Paull \& Chen (1983), who studied the relation between consistency loss, respiration, ethylene evolution and peel color change of 'Sunrise Solo' papaya; these authors found strong relation between these factors and fruit climacteric peak.

Fruit without $\mathrm{KMnO}_{4}$ had consistency of $545.13 \mathrm{kPa}$ on the $3^{\text {rd }}$ day of evaluation, while the treated fruit, at the same day, had consistency mean of $1,536.68 \mathrm{kPa}$, indicating the effect of $\mathrm{KMnO}_{4}$ even after bag removal. These results are in accordance to Oliveira-Júnior et al. (2004), who observed higher pulp consistency in fruit treated with $\mathrm{KMnO}_{4}$, with visible reduction on the first six days, but remaining constant until the end of the refrigerated storage.

Similarly to pulp consistency, the variable electrolyte leakage had no statistical difference between means at the storage beginning and after 25 days in all treatments (Table 1), indicating that cellular membrane kept integrity in the 25 days of storage under refrigeration. Electrolyte leakage showed an exponential behavior in function of the evaluation days, in each dose of $\mathrm{KMnO}_{4}$, with the treatment with $2 \mathrm{~g}$ of $\mathrm{KMnO}_{4}$ per bag presenting the smallest loss of membrane selective permeability (Figure $3 \mathrm{D}$ ). Electrolyte leakage in the fruit without $\mathrm{KMnO}_{4}$ treatment remained stable until the $5^{\text {th }}$ day $(25 \%)$, and then abruptly increased, reaching around $60 \%$ on the $6^{\text {th }}$ day. In treated fruit, electrolyte leakage was stable until the $3^{\text {rd }}$ day, with mean value of $17 \%$, and from then on increased progressively until reaching values between 40 and $50 \%$, on the $6^{\text {th }}$ day.

Membrane selective permeability loss was related to color development and pulp consistency loss. Treatments that maintained membrane selective permeability were also efficient in delaying color development and in reducing pulp consistency loss. The results pointed to an effect of $\mathrm{KMnO}_{4}$ in delaying fruit senescence.

Treatments with 1.5 and $2 \mathrm{~g}$ of $\mathrm{KMnO}_{4}$ per bag had total soluble solids content statistically equal at the storage beginning and after 25 days, while fruit treated with $0,0.5$, and $1 \mathrm{~g}$ of $\mathrm{KMnO}_{4}$ per bag had statistically superior means after 25 days of storage (Table 1), which 

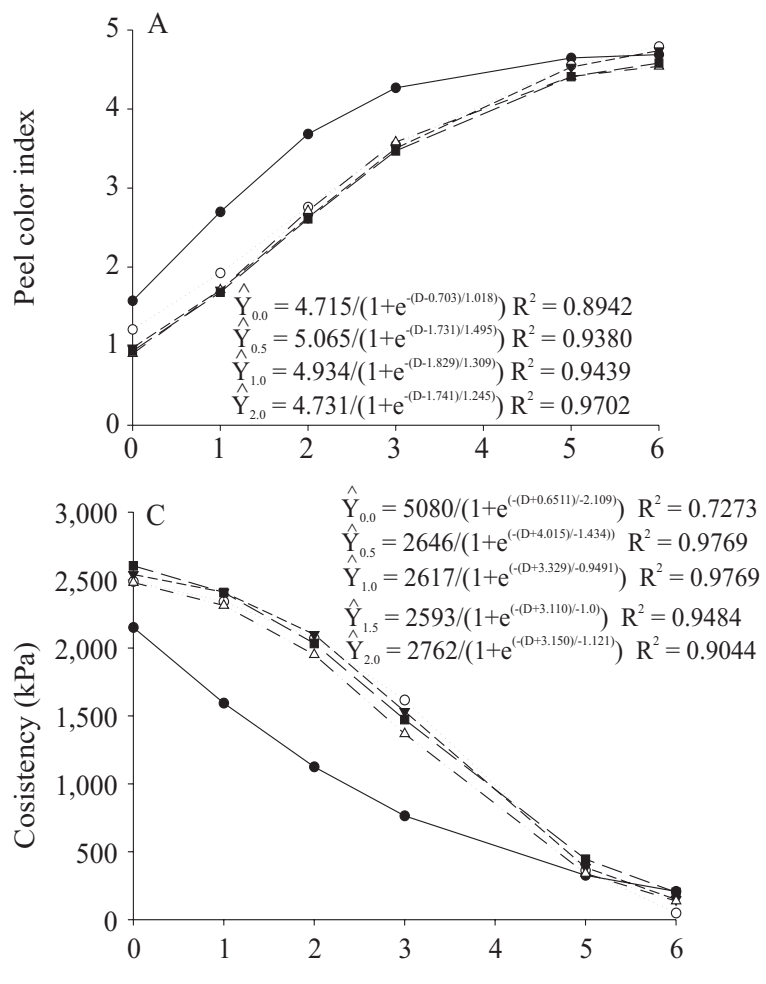
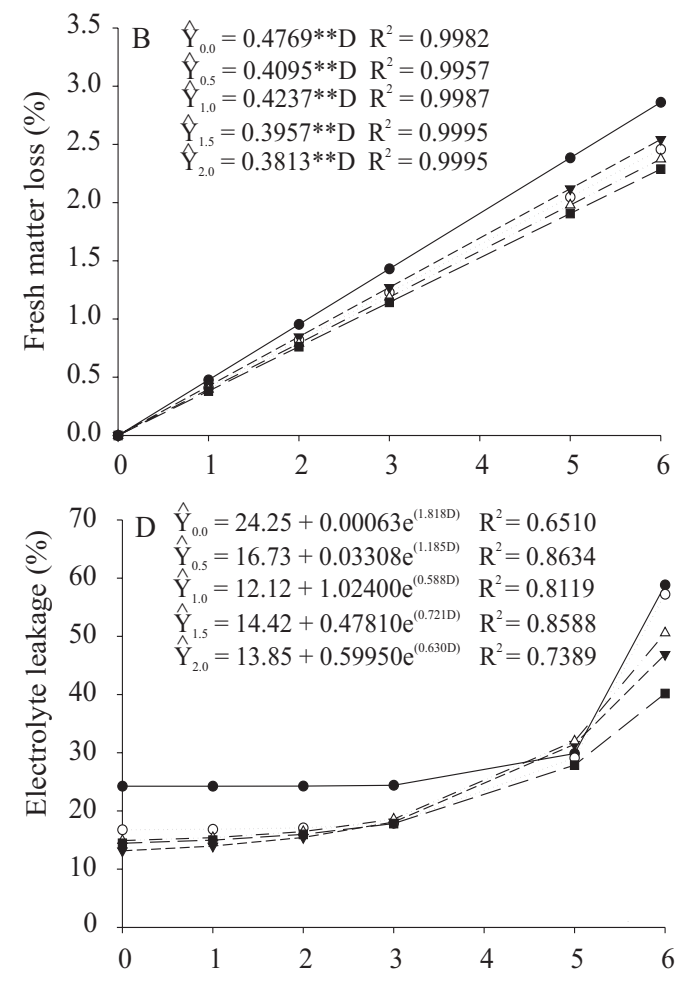

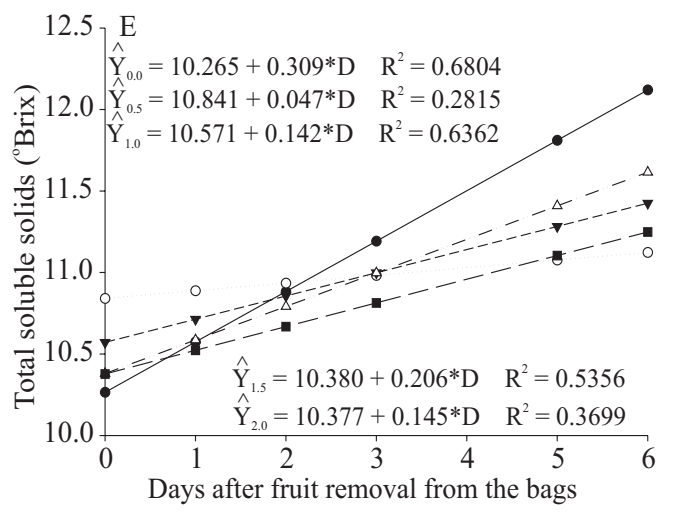

$-\left(\hat{\mathrm{Y}}_{0.0}=0.0 \mathrm{~g}\right.$ of $\mathrm{KMnO}_{4}$ per bag $) \quad \cdots \odot \cdots\left(\hat{\mathrm{Y}}_{0.5}=0.5 \mathrm{~g}\right.$ of $\mathrm{KMnO}_{4}$ per bag $) \quad-\cdots{ }^{-\cdots}\left(\hat{\mathrm{Y}}_{1.5}=1.5 \mathrm{~g}\right.$ of $\mathrm{KMnO}_{4}$ per bag $)$

$-\boldsymbol{\nabla}^{--}\left(\hat{\mathrm{Y}}_{1.0}=1.0 \mathrm{~g}\right.$ of $\mathrm{KMnO}_{4}$ per bag $) \quad--\mathbf{\square}^{-}-\left(\hat{\mathrm{Y}}_{2.0}=2.0 \mathrm{~g}\right.$ of $\mathrm{KMnO}_{4}$ per bag $)$

Figure 3. Peel color index (A), determined by visual scale described by Martins \& Malavasi (2003), fresh matter loss (B), pulp consistency (C), electrolyte leakage (D) and total soluble solids content (E) of 'Sunrise Golden' papaya treated with different doses of $\mathrm{KMnO}_{4}$ and kept at $21 \pm 0.8^{\circ} \mathrm{C}$, after fruit removal from the bags.

indicate an anticipated ripening in these treatments. According to Balbino (2003), papaya has the characteristic of accumulating low contents of starch (less than 1\%) during ripening. After bag removal, the content of total soluble solids showed linear increasing behavior, along the evaluation days, for each dose of $\mathrm{KMnO}_{4}$ (Figure $3 \mathrm{E}$ ). A higher content of soluble solids was observed in the fruit without $\mathrm{KMnO}_{4}$, indicating accelerated ripening, while in treated fruit, $\mathrm{KMnO}_{4}$ effect had a slower evolution of the total soluble solids content. These results are in accordance to the ones obtained by Assis \& Steineker (2003) and by Corrêa et al. (2005). 


\section{Conclusions}

1. Refrigeration combined with fruit wrapping with low density polyethylene film preserve and maintain fruit appearance and some quality attributes during storage for 25 days.

2. Potassium permanganate delays fruit ripening, and the dose $0.5 \mathrm{~g}$ of $\mathrm{KMnO}_{4}$ per bag is sufficient to preserve papaya for 25 days.

\section{Acknowledgements}

To Conselho Nacional de Desenvolvimento Científico e Tecnológico, for the financial support.

\section{References}

ASSIS, J.S.; STEINEKER, M. Qualidade do mamão Solo cv. Golden transportado sob atmosfera controlada em contêiner Rolf. In: MARTINS, D. dos S. (Ed). Papaya Brasil: qualidade do mamão para o mercado interno. Vitória: Incaper, 2003. p.659-662.

BALBINO, J.M. de S. Colheita, pós-colheita e fisiologia do amadurecimento do mamão. In: MARTINS, D. dos S.; COSTA, A. de F.S. da (Ed.). Acultura do mamoeiro: tecnologias de produção. Vitória: Incaper, 2003. p.403-440.

BHADRA, S.; SEN, S.K. Post-harvest storage of custard apple (Annona squamosa L.) fruit var. Local Green under various chemical and wrapping treatments. Journal of Interacademicia, v.1, p.322-328, 1997.

CENCI, S.A.; SOARES, A.G.; SOUZA, M.L.; MOURA, M.L. Efecto de la aplicación de absorvedor de etileno $\mathrm{KMnO}_{4}$ en las características de calidad y conservación de la papaya cv. 'Sunrise Solo'. Revista Iberoamericana de Tecnología Postcosecha, v.1, p.150-155, 1999.

CHAVES, M.A.; BONOMO, R.C.F.; SILVA, A.A.L.; SANTOS, L.S.; CARVALHO, B.M.A.; SOUZA, T.S.; GOMES, G.M.S.; SOARES, R.D. Uso de permanganato de potasio en la preservación post-cosecha de frutas de chirimoya. Ciencia y Tecnología Alimentaria, v.5, p.346-351, 2007.

CHITARRA, M.IF;; CHITARRA, A.B. Pós-colheita de frutos e hortaliças: fisiologia e manuseio. 2.ed. rev. ampl. Lavras: Ufla, 2005. 783p.

CORRÊA, S.F.; SOUZA, M.S.; PEREIRA, T.; ALVES, G.V.L.; OLIVEIRA, J.G.; SILVA, M.G.; VARGAS, H. Determinação da difusibilidade térmica na polpa do mamão (Carica papaya L.,) genótipo 'Golden'. In: MARTINS, D. dos S. (Ed.). Papaya Brasil: mercado e inovações tecnológicas para o mamão. Vitória: Incaper, 2005. p.561-563.

GALVÃO, H.L.; FINGER, F.L.; PUIATTI, M.; CORRÊA, P.C.; OLIVEIRA, L.S. Efeito do pré-resfriamento e do filme de PVC sobre a conservação pós-colheita de brócolis. Revista Brasileira de Armazenamento, v.33, p.101-106, 2008.

GOMEZ, M.L.P.A.; LAJOLO, F.M.; CORDENUNSI, B.R. Metabolismo de carboidratos durante o amadurecimento do mamão (Carica papaya $\mathrm{L}$. cv. Solo): influência da radiação gama. Ciência e Tecnologia de Alimentos, v.19, p.12-15, 1999.

HAO, H.P.; HAO, L. Study on storing strawberry at a temperature near the freezing point of water. Journal of Fruit Science, v.10, p.21-24, 1993.
HONG, Y.P.; HONG, S.S.; KIM, Y.B.; KIM, S.B. Effect of ethylene absorbent (Frubel) on quality of "Hayward" kiwifruit during cold storage. Journal of Agricultural Science, v.38, p.922-926, 1996.

KIM, G.H.; WILLS, R.B.H. Interaction of enhanced carbon dioxide and reduced ethylene on the storage life of strawberries. Journal of Horticultural Science and Biotechnology, v.73, p.181-184, 1998.

MARTINS, D. dos S.; MALAVASI, A. Aplicação do "systems approach" para a exportação de frutas: mamão brasileiro para os Estados Unidos. In: ZAMBOLIM, L. (Ed.). Manejo Integrado: produção integrada, fruteiras tropicais, doenças e pragas. Viçosa, UFV, 2003. p.7-35.

MORAIS, P.L.D. de; MEDEIROS, E.V. de; SILVA, G.G. Conservação pós-colheita e freqüência de fungos em cultivares de mamão. Revista Brasileira de Armazenamento, v.33, p.94-100, 2008.

NEUWALD, D.A.; GIEHL, R.F.H.; SESTARI, I.; BRACKMANN, A. Avaliação de filmes de polietileno para conservação de caqui 'Fuyu' sob refrigeração. Revista Brasileira de Agrociência, v.11, p.95-99, 2005.

OLIVEIRA-JÚNIOR, L.F.G.; COELHO, M.E.; BERBET, P.A.; COELHO, F.C. Armazenamento de mamão 'Golden', em condições de atmosfera modificada. Revista Brasileira de Armazenamento, v.29, p.137-142, 2004.

PAULL, R.E.; CHEN, N.J. Postharvest variation in cell wall-degrading enzymes of papaya (Carica papaya L.) during fruit ripening. Plant Physiology, v.72, p.382-385, 1983.

RESENDE, J.M.; VILAS BOAS, E.V. de B.; CHITARRA, M.I.F. Uso de atmosfera modificada na conservação pós-colheita do maracujá-amarelo. Ciência Agrotécnica, v.25, p.159-168, 2001.

ROCHA, A. Uso de permanganato de potássio na conservação pós-colheita de banana 'Prata'. 2005. 85p. Dissertação (Mestrado) Universidade Federal de Viçosa, Viçosa.

SEREK, M.; TAMARI, G.; SISLER, E.C.; BOROCHOV, A. Inhibition of ethylene-induced cellular senescence symptoms by 1-methylcyclopropene, a new inhibitor of ethylene action. Physiologia Plantarum, v.94, p.229-232, 1995.

SILVA, E.O. Efeito da embalagem plástica e da temperatura sobre a qualidade pós-colheita do mamão. 1995. 65p. Dissertação (Mestrado) Universidade Federal de Viçosa, Viçosa.

SORBENTSYSTEMS. The problem: ethylene gas. Disponível em: $<$ http:// www.sorbentsystems.com/epaxtech.html>. Acesso em: 07 jun. 2005.

SOUZA, B.S. de; DURIGAN, J.F.; DONADON, J.R.; TEIXEIRA, G.H. de A. Conservação de mamão 'Formosa' minimamente processado armazenado sob refrigeração. Revista Brasileira de Fruticultura, v.27, p.273-276, 2005.

TAIZ, L.; ZEIGER, E. Fisiologia vegetal. 4.ed. Porto Alegre: ARTMED, 2009. 820p.

ZAMORANO, J.P.; DOPICO, B.; LOWE, A.L.; WILSON, I.D.; GRIERSON, D.; MERODIO, C. Effect of low temperature storage and ethylene removal on ripening and gene expression changes in avocado fruit. Postharvest Biology and Technology, v.4, p.331-342, 1994

Received on February 10, 2009 and accepted on June 30, 2009 